\title{
Education and the public good: Foregrounding education in history
}

\author{
ET Smith \\ University of Pretoria, Pretoria, South Africa \\ Orcid 0000-0002-8318-4137 \\ edwin.smith@up.ac.za \\ DOI: http://dx.doi.org/10.17159/2223-0386/2021/n26a2
}

\section{Abstract}

Historians can contribute significantly to education historiography to bolster education transformation. Contemporary scholarship in education, in the main, mostly wrestles with the current dispensation's transformation of education policy endeavours in the post-apartheid era. While there is no substantial or insurmountable disagreement on the education policy objectives in post-apartheid South Africa, much of the contestations seem to arise from how these objectives should be realised to achieve their lofty ideals. This is where learning from history is important. History is not merely concerned with constructing knowledge through relooking the past but also attending to the "selection" and "silences" over time. Among other things, South Africa's history also provides significant insights into how education contributed to developing a first-world economy in the country. This article argues that, because of education's ability to enable social and economic mobility to affect families, communities, and society in general positively, education is a public good that requires historians' involvement and attention. The article also considers the significance of funding education as a public good. Consequently, the paper argues that historians can make a significant contribution to transforming education in their continuous rewriting of history to learn from the past and foreground education as a public good in the past and present for the future.

Keywords: History; Education history; Education historiography; Education transformation; Public good. 


\section{Introduction}

Through considering the historiography of education in South Africa, this article seeks to demonstrate a concern regarding historians' lack of engagement with the history of education and the disservice this constitutes to the national transformation efforts currently underway in the country. While there have been notable insights into the development of education over time, the continuous challenge of transforming education to meet the needs and demands of a developing South African education landscape often obscures some of the rich and novel scholarship and debates raging in education historiography. Contemporary scholarship, in the main, mostly wrestles with the current dispensation's transformation of education policy endeavours in the post-apartheid era. There is no substantial or insurmountable disagreement on the education policy objectives in postapartheid South Africa. Much of the contestations seem to arise from realising the lofty ideals encapsulated in these objectives. As this article argues, because of education's ability to enable social and economic mobility, thereby positively affecting families, communities, and society in general, education in South Africa is a public good, albeit this is contrary to views expressed by some scholars in the developed world.

Education is broad and encompasses, i.e., primary, secondary, and post-secondary or tertiary education. However, this article mainly focuses on post-secondary education to illustrate the value, virtue, utility, and significance of education as a public good and its contribution to national development. Given contemporary contestations in the higher education sphere in South Africa, the article also considers the role and importance of higher education funding, particularly for those from historically disadvantaged backgrounds, linking this aspect to the challenges of transforming education in South Africa to the seismic changes post-1994. Although this article reiterates "a call to action" for historians previously issued by other scholars, it amplifies and underscores the significance and importance of historians' involvement in the history of education by locating this contribution within the context of education as a public good. Finally, this article does not seek to theorise, discuss or engage what kind of history of education South Africa needs nor what constitutes "good", "proper", or "useful” education history. These are essential concerns that we should address. As alluded to here, historians will attend to them when they enter the fray and bring their formidable intellectual and professional skills and capabilities to bear on the history of education. 


\section{Education historiography in South Africa}

Quintessentially South African, the history of education can also be read along the precolonial, colonial, apartheid, and post-apartheid continuum and its fault lines. The traditional dichotomies of state imposition and control and public opposition or state-driven and market-directed pushes and pulls frame much of the scholarship on the history of education in South Africa. ${ }^{1}$ With a few exceptions, the periodisation of education historiography also conforms to the categories present in general South African historiography. Consequently, the history of education can be considered, as suggested by Wessel Visser in 2004, that: " $[\mathrm{t}]$ raditionally, historical writings on the history of South Africa has [sic] been divided into broad categories or historiographical schools, namely, a British Imperialist, a settler or colonialist, an Afrikaner nationalist, a liberal, and a revisionist or radical school.” Visser further notes that: " $[\mathrm{t}]$ he emergence of social history is generally also regarded as a byproduct of the revisionist school, while some historians argue that the emergence of a black nationalist historiographical tradition stemmed partly from the radical approach during the years of apartheid". Though the above framework is not the only way to categorise and periodise South African historiography, earlier education historiography focused overwhelmingly on education's response to the development and imposition of racially segregated and apartheid education by state authorities or other economic and social forces shaping education in society. ${ }^{3}$

As indicated earlier, contemporary scholarship mostly wrestles with the transformation of education policy endeavours in the post-1994 context. Notwithstanding this, the utility of this approach continues to be relevant in understanding historical and modern contestations with education in the post-apartheid context. For Jürgen Oelkers and later Michael Cross et.al, "education historiography is not only a question of construction of knowledge but also of selection (of events, names and meanings) and of silences within

1 AH (Kalie) Strydom \& M Fourie, "Higher education research in South Africa", Higher Education, 38(2), 1999, p. 156; B Leibowitz, "Introduction: Reflections on higher education and the public good", B Leibowitz, (ed.), Higher education for the public good: Views from the south. (Stellenbosch: Sun Press, 2012), p. xviii.

2 W Visser, "Trends in South African historiography and the present state of historical research", (Paper, Nordic Africa Institute, Uppsala, Sweden), 23 September 2004, p. 1.

3 AH (Kalie) Strydom \& M Fourie, “Higher education ...", Higher Education, 38(2), 1999, p. 156; B Leibowitz, “Introduction: Reflections on ...", B Leibowitz, (ed.), Higher education for the public good, ..., p. xviii. 
the history of education". ${ }^{4}$ Oelkers sees this predicament as a challenge when he concludes that: "we have no other choice than to rewrite the history of education again and again and to put the process of selection in historiography on as rational a basis as possible".5

Pre-colonial, South African (pre-British imperialist/colonial-settler historiography) education history scholars recently reached the consensus that formal European education in South Africa can be traced back to 1658, before the official establishment in 1662 of the Dutch East India Company's (DEIC) refreshment station at the Cape. ${ }^{6}$ Johannes Seroto postures that "forms of formal and informal teaching and learning existed among the indigenous peoples of Southern Africa before the arrival of the European in the Cape Colony in 1652", 7 which is now referred to as the pre-colonial period in history. According to Seroto, "the children of indigenous peoples in Southern Africa learned in different ways, where in the early years they learned much from their mother and extended family and formally through initiation ceremonies". However, "indigenous education, which was predominantly informal, prevailed before formal and institutionalised education was introduced by the European settlers on their arrival in the Cape".

Speaking about European schooling at the Cape, Wolhuter reports that the colonial period, which he dates as 1652 to 1910 , was a typically colonial set-up based on racial segregation. The Dutch East India Company established the first formal slave school in $1658 .^{10}$ From a very early age, Cape education was characterised by the colonial

4 J Oelkers, "Nohl, Durkheim, and Mead: Three different types of 'history of education", Studies in Philosophy and Education, 2004, 23, p. 365; M Cross et.al, "Unfulfilled promise: radical discourses in South African educational historiography, 1970-2007”, History of Education. 1(26), 2008, p. 3.

5 J Oelkers, "Nohl, Durkheim, and Mead: Three different...", Studies in Philosophy and Education, 23, 2004, p. 365.

6 CC Wolhuter. "Teacher training in South Africa: Past, present and future", Education Research and Perspectives, 33(2), 2006, p. 124; "History of Education in South Africa". Available at https://www.k12academics.com/Education\%20Worldwide/Education\%20in\%20South\%20Africa/history-education-south-africa Accessed on 12 January 2021; "Amersfoort Legacy - History of education in South Africa", South African History Online. Available at https://www.sahistory.org.za/article/amersfoort-legacy-history-education-south-africa\#: :text=The\%20opening\%20moment\%20of\%20education,school\%20is\%20begun\%20 in\%201658. Accessed on 12 January 2021.

$7 \mathrm{~J}$ Seroto. "Indigenous education during the pre-colonial period in Southern Africa", Indilinga-African Journal of Indigenous Knowledge Systems, 10(1), 2011, pp. 77-78.

8 J Seroto, “Indigenous education", Indilinga-African Journal of Indigenous Knowledge Systems, 10(1), 2011, p. 78 .

9 J Seroto, “Indigenous education”, Indilinga-African Journal of Indigenous Knowledge Systems, 10(1), 2011, p. 85.

10 C Wentzel, "Interactive timeline of the history on the educational policy in South Africa", Sutori, 29 November 2018. Available at https://www.sutori.com/story/interactive-timeline-of-the-history-on-the-educational-policy-in-south-africa-- $x$ EYiK8yVhmycHJqEcLmR2X3w. Accessed: September 2021. 
government's involvement in the education of white children, recruiting teachers for white schools from the Netherlands, and after 1810 from England. ${ }^{11}$ Literature on formal school education in South Africa supports the view that, following the colonisation of modern-day South Africa, the first "free" farmers who were allowed to settle in the Cape in 1657 were Dutch before England finally colonised the Cape in $1806 .{ }^{12}$ Wolhuter also notes that the later Boer Republics of the Transvaal and the Orange Free State recruited teachers from the Cape Colony and the Netherlands. When the Rev SJ Du Toit became the Superintendent of Education and promulgated the Education Act of 1882, it provided for establishing an institution for the training of teachers and civil servants in Pretoria, the Transvaal capital at the time. Consequently, the institution was opened in 1883 and operated till 1887. Following the Transvaal becoming a British colony in 1902, the colonial administration, being reluctant to continue importing teachers from the Netherlands, established a teacher's training college, the Pretoria Normal College. ${ }^{13}$ The Pretoria Normal College was established on 2 September 1902, with its campus in Rissik Street, Sunnyside, Pretoria. Initially an English medium institution, it became an Afrikaans college in $1933 .{ }^{14}$

From 1910 to 1948 (Afrikaner Nationalism), also regarded as the pre-apartheid era, was characterised by continued racialised education and the establishment of the national education system. ${ }^{15}$ The Union of South Africa government was established in 1910. It was the amalgamation of the Cape Colony, the Orange Free State, Transvaal, and Natal, which had federal dimensions that assigned the responsibility of education for whites to the four provincial governments. ${ }^{16}$ During the apartheid era (1948 to 1994), historians describe racialised education as becoming draconian with the introduction of education policies to bolster racially separate and unequal education for the different population groups in the country. Accordingly, the state asserted control over missionary schooling and segregated black education through fragmentation and differentiation of the education system. ${ }^{17} \mathrm{~A}$

11 CC Wolhuter, "Teacher training in South Africa”, Education Research and Perspectives, 33(2), 2006, pp. 125-126.

12 CC Wolhuter, “Teacher training ...”, Education Research and Perspectives, 33(2), 2006, p. 125.

13 CC Wolhuter, "Teacher training in South Africa", Education Research and Perspectives, 33(2), 2006, pp. 126-127.

14 "1902: Pretoria Normaal-kollege stigting", Gelofteland. Available at http://www.gelofteland.org/index. php/ons-volk/23-kultuurdagboek/1551-1902-pretoria-normaal-kollege-gestig.html. Accessed on September 2021.

15 P Kallaway, "The forgotten history of South African education", Southern African Review of Education, 18(1), 2012, p. 16.

16 CC Wolhuter, “Teacher training ...”, Education Research and Perspectives, 33(2), 2006, p. 127.

17 M Cross, "A historical review of education in South Africa: Towards an assessment", Comparative Education, 22(3), 1986, p. 191. 
host of legislation promulgated by the white minority ruling section of the South African population, generally under the auspices and leadership of the Afrikaner Nationalist government, supported this effort. Seminal education legislation such as the Bantu Education Act of 1953, the Extension of University Education Act of 1959, the Coloured Person's Education Act of 1963, and the Indian Education Act of 1965 were keystone achievements in setting the nature driving the tone of formal education in the country.

These various acts established different departments to operate and navigate the new education landscape. In the case of Bantu Education, the Department of Native Affairs took control of black education; the Department of Coloured Affairs took responsibility for the education of people of mixed descent, and finally, the Department of Indian Affairs took responsibility for the education of persons from Indian descent in the country. ${ }^{18}$ The Minister of Native Affairs later renamed the Bantu Administration and Development, drafted the Bantu Education Act. ${ }^{19}$ Apart from race, schools and universities were also classified and segregated according to ethnicity. ${ }^{20}$ These efforts were not unchallenged or unopposed and formed the bedrock and foundation of education policy, thinking, and practice in South Africa. It resulted in Michael Cross considering the problem of race, gender, location, and authorship as major issues in the South African education history, from the apartheid era to the present. ${ }^{21}$

Peter Kallaway noted that there was "curiously little material on the apartheid period from 1948-1994"22 in education historiography. Cross postulates that the development of the school crisis between 1976 and 1980, triggered by the student uprising against the imposition of Afrikaans as an instruction medium in schools as part of apartheid education, resulted in many social scientists committing to a more nuanced approach to studying education in South Africa. ${ }^{23}$ Cross et al., argue that: "the transition from apartheid society and the process of national reconstruction came to be thought about within the horizon

18 Y Booley, "The role of education in the challenges faced by South Africa in the $21^{\text {st }}$ century", 2017, pp. 4-5. Available at http://www.wynghs.co.za/storage/news/Science-essay-Yusra-Booley.pdf. Accessed on 12 January 2021.

$19 \mathrm{H}$ Tomlin, "Contesting ideologies and the struggle for equality: Reconsidering the politics of education in South Africa", Policy Features in Education, 14(6), 2016, p.848.

20 D Hay \& M Monnapula-Mapesela, "South African higher education before and after 1994", E Blitzer (ed.), Higher Education in South Africa, 2009, p. 12.

21 M Cross et al., "Unfulfilled promise: radical discourses in South African educational historiography, 1970-2007", History of Education, 1(26), 2008, p. 3.

22 P Kallaway, "The forgotten history of South African education", Southern African Review of Education, 18(1), 2012, p. 17.

23 M Cross, "A historical review of education", Comparative Education, 22(3), 1986, p. 185; M Cross et.al, "Unfulfilled promise", History of Education, 1(26), 2008, p. 1. 
of possibilities different from the rigid paradigmatic tradition in which radical change was conceptualised by the short-lived radical-neo-Marxist school of the 1970s and 1980s in South African education". ${ }^{4}$

With the advent of democracy in South Africa in 1994, the new South African government formulated a national education policy. According to Wolhuter, it was based on the principles of democratisation characterised by active participation by all parties, particularly teachers, pupils/students, parents, and the community. There would be equal education opportunities for all and desegregation, where one of the first steps taken in the field of education should be the collapse of homeland education ministries. The white, Indian, and coloured education ministries would be combined into one National Department of Education. Multiculturalism, had to be established, where the entire education system was to be geared towards realising the potential of the entire population, with the societal objectives of economic development and the moulding of national unity as final goals. ${ }^{25}$ Furthermore, Kalie Strydom and Magda Fourie observed that: "the changes in the political sphere and the omens of the demise of apartheid brought to the higher education debate other focus points, such as the conflict of values and interests in higher education; the tension between quality and equality; and the redefinition of the mission of higher education". ${ }^{26}$

As can be discerned, these policy objectives directly respond to the historical trajectory of formal education in South Africa, where colonial and apartheid governments sought to achieve the direct opposite of what the new democratic dispensation now aims to achieve. Furthermore, objectives similar to those of the post-apartheid education policy were also integral to the political struggle against colonialism and apartheid of the indigenous, oppressed, and exploited black majority of the South African population in partnership with sympathetic and supportive formations locally and abroad. Though laudable by any measure, these objectives have resulted in remarkable contestations in the modern South African education landscape. Currently, it is a landscape viewed by many as untransformed in terms of the lived experiences of the majority of the historically disadvantaged South Africans - a modern euphemism for black South Africans. They continue to be trapped in the colonial and apartheid geopolitical and spatial constructs of the townships and rural areas in the country and continue to suffer the legacy of the unequal funding of education

24 M Cross et al., "Unfulfilled promise", History of Education, 1(26), 2008, p. 2.

25 CC Wolhuter, “Teacher training in South Africa”, Education Research and Perspectives, 33(2), 2006, p. 131.

26 K Strydom \& M Fourie, “Higher education research”, Higher Education, 38(2), 1999, p. 156. 
bequeathed by the previous dispensations.

In his 2012 survey of South African education historiography titled "The forgotten history of South African education”, Peter Kallaway, echoing Andy Green, cautions that: "although there are many sound analyses of the fundamental role of mass education in the constitution of $20^{\text {th }}$ century society and its successes and failures, it can be argued that this story has not fully taken its rightful place as a central aspect of mainstream history, despite numerous attempts by educational historians to chart the field". ${ }^{27}$ For Kallaway, what is revealed in his survey of South African historiography, "is that South African historians, whether liberal, Afrikaner nationalist, Africanist, revisionist or those belonging to the social history or popular history traditions, have on the whole not placed education at the centre of the historical picture" ${ }^{28}$ This leads him to further caution against what he sees as "the baby and bathwater phenomenon" in contemporary South African historiography and education policy development. Kallaway notes that: "in the South African case, the attempt to characterise the whole history of education as flawed on account of its association with apartheid led to the wholesale abandonment of educational traditions built up over two centuries" ${ }^{29}$ Kallaway postulates that it would serve South African historiography and policy development well if "the successes and failures of the post-1994 system are to be understood in terms of the continuity with that past as well as the ruptures and innovations" 30 that occurred during this period.

Kallaway also observed that the period before 1910 proved to be the least researched. The major focus had been on 1910-1948 when the national education system was established. He points out that there was curiously little material on the apartheid period from 1948-1994. ${ }^{31}$ Regarding this period, he notes that: "there is a major emphasis on black education and the opposition to Bantu Education, but there is very little consideration of the literature related to the People's Education Movement or any careful exploration of the issues related to 'liberatory education' and the links to worker education in the emergent black unions" ${ }^{32}$ Kallaway concludes that: "the $21^{\text {st }}$ century [in South Africa] is notable for the lack of attention to history and an unwillingness to see contemporary political culture

27 P Kallaway, "The forgotten history", Southern African Review of Education, 18(1), 2012, p. 9; A Green, Education and state formation: The rise of education systems in England, France and the USA, (London: Macmillan), 1990.

28 P Kallaway, "The forgotten history", Southern African Review of Education, 18(1), 2012, p.12.

29 P Kallaway, "The forgotten history", Southern African Review of Education, 18(1), 2012, p.12.

30 P Kallaway, "The forgotten history", Southern African Review of Education, 18(1), 2012, p. 13.

31 P Kallaway, "The forgotten history", Southern African Review of Education, 18(1), 2012, p. 17.

32 P Kallaway, "The forgotten history”, Southern African Review of Education, 18(1), 2012, pp. 16-17. 
through the lens of past experience". ${ }^{33}$

Akin to some of the effects noted about the 1976 student uprisings on the study of education, ${ }^{34}$ more recently, Linda Chisholm et al., observed that "the \#Rhodesmustfall and \#Feesmustfall student campaigns of 2015 and 2016 in South Africa brought into sharp focus the centrality of history to the debate about the decolonisation of the university curriculum". ${ }^{35}$ In their study, they note that: "while there has been some research into the nature of the history of curriculum in post-apartheid [sic] South Africa, the nature of the history of education in teacher training has not received a great deal of attention" ${ }^{36}$ Their study, which echoes Kallaway's observations noted earlier, revealed "the continued intellectual, academic apartheid that exists in South Africa, and the failure to create a history of education in South Africa that does full justice to the intellectual approaches and research that do exist". ${ }^{37}$

As observed earlier, there is no substantial or insurmountable disagreement on the education policy objectives of the post-apartheid South African context, and much of the contestations seem to arise from how these objectives are to be realised. While the first part of this contention may seem located in the technical sphere of policy development and implementation and the second part in the political sphere, nuanced reading of these issues reveals some consensus in the public's view of the value and utility of education. That is education is a "public good" that needs to be harnessed to address the inequalities bequeathed by the colonial and apartheid legacies. As this article seeks to demonstrate, this view is also informed by the historical trajectory of the development and evolution of formal education in South Africa. Supporting this notion, Strydom and Fourie confirm that the higher education system in post-apartheid South Africa is characterised by, among other things,

an unmatched obligation, which has not been adequately fulfilled, to help lay the foundations of a critical civil society, with a culture of public debate and tolerance which accommodates differences and competing interests. It has to do much more, both within its own institutions and through its influence on the broader community, to strengthen the

33 P Kallaway, "The forgotten history”, Southern African Review of Education, 18(1), 2012, p. 18.

34 M Cross et.al, "Unfulfilled promise", History of Education, 1(26), 2008, p. 1.

35 L Chisholm, et.al, “Decolonising ...”, Southern African Review of Education, 24(1), 2019, p. 75.

36 L Chisholm, et.al, “Decolonising ...”, Southern African Review of Education, 24(1), 2019, p. 75.

37 L Chisholm, et.al, “Decolonising ...”, Southern African Review of Education, 24(1), 2019, p. 87. 
democratic ethos, the sense of common citizenship and commitment to a common good. ${ }^{38}$

In her South African university history overview, Bronwyn Strydom of the University of South Africa notes that "[South African university] history has a long tradition of commemorative writing which, while breaking ground in terms of the recording of the history of individual institutions, does not always conform to historical methodology or critical distance".39 Strydom further notes that "South African universities have attracted some scholarly attention, especially more recently, and this new interest has also demonstrated the value of the historical study of institutions of higher education". ${ }^{40}$

The lack of involvement of historians in documenting the history of education is evident. It is critical in ensuring a deeper appreciation of the historical fault lines in the development of education in the modern context with possibly devastating consequences for the societal transformation project in contemporary South Africa. It also demonstrates the challenges and opportunities historians have in foregrounding education history to assist and support education policy development in addressing the historically generated disjuncture in education currently being attended to as modern challenges void of antecedents. The continuities and breaks in education policy development over the past decades in South Africa are critical in ensuring meaningful interventions with a greater chance of success in transforming education as a public good for the benefit of society in general and the historically disadvantaged in particular.

\section{The value of education as a public good}

As indicated earlier, while education encompasses primary, secondary, and postsecondary education, this article focuses mainly on post-secondary education. The purpose is to illustrate the concerns, contestations, opportunities, and implications for education historians to enable social and economic mobility and positively affect families, communities, and society in general, which is a crucial characteristic leading to education being viewed as a public good. However, and like so much else, the idea that education is a public good enjoys much debate in contemporary society and academic literature.

38 K Strydom \& M Fourie, "Higher education research in South Africa”, Higher Education, 38(2),1999, p. 161.

39 B Strydom, "South African university history: A historiographical overview", African Historical Review, 48(1), 2016, pp. 56-57.

40 B Strydom, “South African university history: ..., African Historical Review, 48(1), 2016, p. 57. 
In his Edmund Rich Memorial Lecture at Oxford University in 1995, the economist Richard Smethurst argued that education is neither solely a public nor a private good. For Smethurst, it is both. Some education is overwhelmingly a public good as its benefits accrue very widely to society and the individual. Simultaneously, while benefiting society, some education offers more overwhelming benefits to the individual than society. ${ }^{41}$ Jan Polcyn offered another treatise in 2015 of "Education as a public good" in the Bulletin of the Berdyansk University of Management and Business. ${ }^{42}$ However, for economists, as argued by Jane Shaw earlier in 2010, a public good is not simply "good for the public". ${ }^{43}$ It is also something that benefits many people, including those who do not pay for it. Advanced education falls in this category as fostering greater productivity and innovation, improving the lives of everyone, not just those who bought the education. ${ }^{44}$

Education carries with it the implications of improving the lives of individuals, enabling their social and economic mobility, which in turn benefits the broader society. This particular feature, i.e., individual before social benefits, seems to trouble the waters somewhat in the debate about whether education is a public good or not. From a business perspective, education is simply a private good for which the individual seeking it must pay. On the other hand, education as a public good is public investment and the state's responsibility.

Furthermore, in Europe, education has also been regarded as a transnational (global) good. In this context, treating education as a public good allows for a strategic perspective on the benefits of education. On the one hand, it leads to the personal development of the individual, and, on the other, it provides global benefits for whole societies under the inductive effects of education because education undoubtedly contributes to the creation of social capital, which is treated as public, or at least a quasi-public, good. ${ }^{45}$ Furthermore, the ministers of the European Union at a summit on higher education in Prague in 2001 jointly declared that higher education is "a public good" and "a public responsibility". They further stated that education, especially higher education, was considered one of the most

41 R Smethurst, "Education: a public or private good?", RSA Journal, 143(5465), 1995, p. 38.

$42 \mathrm{~J}$ Polcyn, "Education as a public good", Bulletin of the Berdyansk University of Management and Business, 1(29), 2015, p. 32; R Smethurst, “Education: a public or private good?”, RSA Journal, 143(5465), 1995, p. 37.

43 JS Shaw, "Education-A bad public good", The Independent Review, 15(2), 2010, p. 241.

44 JS Shaw, "Education-A bad public good", The Independent Review, 15(2), 2010, p. 241.

$45 \mathrm{~J}$ Polcyn, "Education as a public good", Bulletin of the Berdyansk University of Management and Business, 1(29), 2015, p. 33. 
important public goods and, as such, a necessity and responsibility of the state. ${ }^{46}$

In 2016 Gareth Williams from the University College London argued that the financial, socio-political, and ideological pressures on the public fiscus have contributed to replacing higher education as a public service, with it being considered a marketable commodity, subject to the laws of supply and demand by individuals and organised groups. ${ }^{47}$ In this regard, the focus of the debate is on how higher education should be paid for, ${ }^{48}$ instead of its value and meaning to society, particularly given the competition of other services on the public fiscus.

This debate has adopted a different tone in Africa. Mainstream, Western, higher education concepts and the public good, underpinned by particular understandings of higher education's nature and form and how knowledge is acquired, developed, and disseminated, are far removed from the reality of highly unequal, socially stratified, and politically complex societies within which higher education is often deeply embedded. ${ }^{49}$ In 2008, Mahmood Mamdani traced the debate on education as a public good in Africa to the "Bretton Woods Institutions ${ }^{50}$ and the Assault on the Developmentalist University" of postcolonial Africa. Here the "World Bank began with a frontal assault on African universities at a conference of Vice Chancellors of African universities that it called in Harare in 1986" ${ }^{51}$ Mamdani observed that "the [World] Bank had a substantial critique of the developmentalist university [which led it to conclude] that the beneficiaries should share a significant part of the cost of higher education and that the state should reduce [its] funding to higher education". 52 Mamdani proffers that "overall, the Bank framed a debate in which the private and the public, the market and the state, were seen more as alternatives

46 E Kocaqi (Levanti), "Higher education a private or a public good?", Academic Journal of Interdisciplinary Studies, 4(3), 2015, p. 432.

47 G Williams, “Higher education: Public good or private commodity?", London Review of Education, 14(1), 2016, pp. 132, 134.

48 G Williams, "Higher education...?”, London Review of Education, 14(1), 2016, p. 139.

49 E Unterhalter et al., "Conceptualising higher education and the public good", (Paper, CIES conference in Mexico City), March, 2018, p. 2.

50 The Bretton Woods Institutions are the International Monitory Fund (IMF) and the International Bank for Reconstruction and Development (later known as the World Bank), which were established at a United Nations' Monetary and Financial Conference held at Bretton Woods, New Hampshire, USA, in the summer of 1944 to facilitate international cooperation in the field of economics. These institutions were established near the end of World War II (1939 to 1945) to regulate and promote a new world financial order-JW Pehle, “The Bretton Woods Institutions”, Yale Law Journal, 55, 1946, pp. 1127-1128.

51 M Mamdani, "Higher education, the state and the marketplace", Journal of Higher Education in Africa, 2008, p. 7.

52 M Mamdani, "Higher education, ...”, Journal of Higher Education in Africa, 2008, p. 8. 
rather than complementaries between which there needed to be appropriate relations". ${ }^{3}$

However, in her introduction to Higher education for the public good: Views from the South ${ }^{54}$ Brenda Leibowitz of the University of Johannesburg noted that: "[a]11 policy statements emanating from the South African state about higher education stress the imperative to transform education so that it becomes more equitable in terms of participation and governance, and so it contributes to the public good and social justice". ${ }^{55}$ Leibowitz further indicated that, for South Africa, the public good of education was concerned "with participatory parity and equality, not the privileged and wealthy administering charity to the marginalised". ${ }^{56}$ Joy Papier, in her 2014 review of Higher education for the public good: Views from the South, noted that rather than the "public good" being an esoteric notion, the book served to concretise the concept, through its combination of philosophical and empirical contributions. ${ }^{57}$

In 2018, Elaine Unterhalter from the University College London and her colleagues further noted that there seem to be two rather distinct ways in which higher education and the public good have been conceptualised. In the first, higher education is "instrumental" in shaping a version of the public good where its qualifications, knowledge production, innovation, development of the professional classes, and expertise are perceived to lead to particular manifestations of public good, delineated as economic, social, political or cultural. The second is higher education as "intrinsic", where the intellectual, physical, and cultural experiences enabled through higher education express and enact the public good, e.g., prejudice reduction, democratisation, critical thinking, and active citizenship. ${ }^{58}$ A reconceptualisation of the public was required in these contexts and some challenge to contemporary conceptualisations of the private, given the strong obligations of individuals to extended families and the sharing of the benefits of higher education amongst their communities of origin. ${ }^{59}$

There are visible shifts in the international community regarding who should pay for higher education. It suggests a shift from higher education being a public good, for which

53 M Mamdani, "Higher education, ...", Journal of Higher Education in Africa, 2008, p. 8.

54 B Leibowitz, (ed.), "Introduction: Reflections on higher education and the public good", Higher education for the public good: Views from the South, (Stellenbosch: Sun Press, 2012), p. xix.

55 B Leibowitz, (ed.), "Introduction", Higher Education for the Public Good: ..., (, p. xxi.

56 B Leibowitz, (ed.), "Introduction", Higher Education for the Public Good: ..., , p. xxii.

57 J Papier, "Review: Leibowitz, Brenda (2012)“. "Higher education for the public good: Views from the south”, Journal of Student Affairs in Africa, 2(1), 2014, p. 89.

58 E Unterhalter et al., "Conceptualising higher education and the public good", (Paper, CIES conference in Mexico City, March 2018), p. 18.

59 E Unterhalter et.al, “Conceptualising ...”, (Paper, CIES conference in Mexico City, March 2018), p. 21. 
the state should be responsible, to being a private good for which the individual seeking such education should be accountable. In Africa there are debates about the public good of higher education that seek to reconceptualise the notion and contextual meaning and implications of this concept for the African experience. ${ }^{60}$ It is due to several reasons, which, among other things, are rooted in South Africa's history with higher education and the recent massive transformation of South African society post-1994. Furthermore, and different from "the public good often [being] defined in material terms, as if it is visible, countable or weighable, $[\ldots]$ the public good is associated with how people or groups think and behave". ${ }^{61}$

The legacy of apartheid is an unequal society based on race and ethnic differences promulgated by statutes in the pre-1994 dispensation. There have not yet been debates on who must foot the bill for equity, equality, and access to higher education for those historically and deliberately barred from such access - despite the fact that the state is responsible for transforming South African society and addressing the historic disadvantages visited on the black majority of its citizens. Current debates grapple with the transformation of the higher education system and improving access for the majority of the traditionally excluded populations in the country. It is quite possible that sometime in the future, with the appropriate massification of the system, the debate on who must pay for higher education might also rear its head in South African society. Although there is consensus that the state is responsible for providing higher education to the historically disadvantaged community members, the issues are to what extent and how well this should happen.

In the context of this article, it is critical to note that, though education as a public good is currently being debated globally, in South Africa and on the African continent, education seems to be considered a public good. Though this can largely be attributed to education's ability to transform people and society from the ravages of colonialism and apartheid, it was also considered a public good in the context of the colonial and apartheid eras in South Africa, albeit with a clear focus on the good being for white South Africans

60 B Leibowitz, (ed.), "Introduction", Higher education for the public good: Views from the South, (Stellenbosch: Sun Press, 2012), p. xix.

61 B Leibowitz, (ed.), “Introduction", Higher education for the public good: ..., p. xxii. 
only. Accordingly, the communities of the South ${ }^{62}$ are engaged in efforts to reconceptualise the public and the private aspects of education as a public good with the view to its utility for social development and transformation, which are critical challenges for these communities. Furthermore, the 2015 to 2018 movements driven by the \#Rhodesmustfall and \#Feesmustfall illustrated, among other contestations, a view of a large segment of South African society that higher education should be accessible to the historically disadvantaged populations in the country. Consequently, on 16 December 2017, Reconciliation Day in South Africa, the then South African President, Jacob Zuma announced that government would subsidise free higher education for poor and working-class students. ${ }^{63}$ Responding to President Cyril Ramaphosa's State of the Nation Address (SONA) of 2019, the Minister of Higher Education, Science and Technology, Dr Blade Nzimande, reported that: "In line with the President's focus, over the next 10-year period our department will focus on the effectiveness and expansion of the new bursary scheme in both the university and TVET college sectors [and confirmed that s] tudents from families earning less than R350 000 per annum [will] receive comprehensive support in the form of a bursary for the duration of their studies. ${ }^{64}$

Given the challenges of transformation in the higher education sector in South Africa, a fundamental impediment is a reality that "while South Africa's economy [may be] the largest in Africa, it significantly lags behind [that of] developed nations, and this restricts the extent to which it can fund public higher education. Furthermore, funding for public higher education in South Africa is comparatively lower than in countries at a similar stage of economic development". ${ }^{65}$ Consequently, in agreement with Leibowitz, one of the severe limitations "of the sector, as well as a motivating force for change, is the degree of financial

62 According to David Slater in his inaugural address at Loughborough University in the UK in 1995, the terms "North/South" are categorisations that "have been employed within the interpretative arena to draw our attention to the nature of global disparities", whose usage raises significant questions concerning the representation of the other in international relations. For instance, they can encourage us to examine the dominant forms of enframing non-Western others that have been deployed across a long sweep of geopolitical history-D. Slater. "Geopolitical imaginations across the north-south divide: issues of difference, development and power”, Political Geography, 16(8), 1997, p. 634.

63 Z Areff \& D Spies, “Zuma announces free higher education for poor and working class students”, News 24 , 16 December 2017.

64 BE Nzimande, "A Dream for a better South Africa", (Address, Minister of higher education, science and technology, 2019 State of the nation address debate), 25 Jun 2019. Available at https://www.gov.za/ speeches/minister-nzimande-debate-state-national-address-25-jun-2019-0000 Accessed on 30 June 2019.

65 I Scott, "First-year experience as terrain of failure or platform for development? Critical choices for higher education". B Leibowitz, S van Schalkwyk, and A van der Merwe, (eds.), Focus on first-year success: Perspectives emerging from South Africa and beyond. (Stellenbosch: Sun Media Press, 2009), p. 20. 
inequality between higher education institutions and between individuals $[\ldots]$ and the low and skewed participation of the appropriate cohort of 18-24-year olds by race”. ${ }^{66}$

\section{Conclusion: A call to arms for historians}

Having considered the historiography of education in South Africa and the conceptualisation of education as a public good, it is clear that South African education will be wrestling with the ghost of its colonial and apartheid legacies for the foreseeable future. It is also clear that centering education history in these debates is critical in ensuring that the development and continuous evolution of education policy and practice benefit from the successes and failures of education in the country, from the pre-colonial to the colonial/apartheid era, right up to the post-apartheid context. The current state of education historiography also provides opportunities for renewed engagement with the history of education with a view to a fuller, more complex, and nuanced understanding of precisely how South Africa was able to achieve a first-world education status while simultaneously subjecting the majority of its citizens to education backwardness that threatens the embedding and development of a meaningful democratic dispensation in the post-apartheid context. Taking up Oelkers's call to arms for historians, we need to consider, foreground, and rewrite the history of education. This could perhaps assist in developing meaningful solutions to South Africa's pressing and serious policy challenges going into the new and unchartered future.

66 B Leibowitz, (ed.), “Introduction”, Higher education for the public good: ..., p. xix. 


\section{References}

History of Education in South Africa. Available at https://www.k12academics.com/ Education\%20Worldwide/Education\%20in\%20South\%20Africa/history-educationsouth-africa. Accessed on 12 January 2021.

Areff, Z \& Spies, D. 2017. Zuma announces free higher education for poor and workingclass students. News24, 16 December.

Booley, Y. 2017. The role of education in the challenges faced by South Africa in the $21^{\text {st }}$ century. 1-14. Available at http://www.wynghs.co.za/storage/news/Science-essayYusra-Booley.pdf Accessed on 12 January 2021.

Chisholm, L. et al., 2019. Decolonising history of education in South African teacher education. Southern African Review of Education. 24(1):74-91.

Cross, M. 1986. A historical review of education in South Africa: towards an assessment. Comparative Education. 22(3):185-200.

Cross, M, Carpentier, C \& Ait-Mehdi, H. 2008. Unfulfilled promise: radical discourses in South African education historiography, 1970-2007, History of Education. 1-26.

Green, A. 1990. Education and State Formation: the rise of education systems in England, France, and the USA. London: Macmillan.

Hay, D \& Monnapula-Mapesela, M. 2009. South African higher education before and after 1994 E Blitzer (ed.). Higher Education in South Africa. 3-49.

Kallaway, P. 2009. The forgotten history of South African education. Southern African Review of Education. 18(1):7-23.

Kocaqi (Levanti), E. 2015. Higher education a private or a public good? Academic Journal of Interdisciplinary Studies. 4(3):432-435.

Leibowitz B (ed.). 2012. Higher education for the public good: views from the south. Stellenbosch: Sun Press.

Mamdani, M. 2008. Higher education, the state, and the marketplace. Journal of Higher Education in Africa. 1-10.

Nzimande, B.E. 2019. A Dream for a better South Africa. (Address, Minister of higher education, science and technology, 2019 State of the nation address debate). Available at https://www.gov.za/speeches/minister-nzimande-debate-state-national-address25-jun-2019-0000. Accessed on 30 June 2019.

Oelkers, J. 2004. Nohl, Durkheim, and Mead: Three different types of 'history of education'. Studies in Philosophy and Education. 23:347-366. 
Papier, J. 2014. Review: Leibowitz, Brenda (2012). Higher education for the public good: views from the South. Journal of Student Affairs in Africa. 2(1):89-92.

Pehle, J.W. 1946. The Bretton Woods institutions, Yale Law Journal, 55:1127-1139.

Polcyn, J. 2015. Education as a public good. Bulletin of the Berdyansk University of Management and Business. 1(29): 32-35.

Scott, I. 2009. First-year experience as terrain of failure or platform for development? Critical choices for higher education. B Leibowitz, S van Schalkwyk, and A van der Merwe, (eds.). Focus on first-year success: perspectives emerging from South Africa and beyond. Stellenbosch: Sun Media Press.

Shaw, JS. 2010. Education-A bad public good. The Independent Review. 15(2):241-256.

Seroto, J. 2011. Indigenous education during the pre-colonial period in Southern Africa. Indilinga-African Journal of Indigenous Knowledge Systems. 10(1):77-88.

Slater, D. 1997. Geopolitical imaginations across the north-south divide: issues of difference, development, and power. Political Geography. 16(8):631-653.

Smethurst, R. 1995. Education: a public or private good? RSA Journal. 143(5465):33-45.

Strydom, B. 2016. South African university history: a historiographical overview. African Historical Review. 48(1):56-82.

Strydom, K \& Fourie, M. 1999. Higher education research in South Africa: achievements, conditions and new challenges. Higher Education. 38(2):155-167.

Tomlin, H. 2016. Contesting ideologies and the struggle for equality: reconsidering the politics of education in South Africa. Policy Features in Education. 14(6):846-863.

Unterhalter, E, Allais, S, Howell, C, McCowan, T, Morley, L, Oanda, I \& Oketch, M. 2018. Conceptualising higher education and the public good in Ghana, Kenya, Nigeria, and South Africa. (Paper, CIES conference in Mexico City, March), 1-32.

Visser, W. 2004. Trends in South African historiography and the present state of historical research. Paper, Nordic Africa Institute, Uppsala, Sweden. 23 September, 1-19.

Wentzel, C. 2018.Interactive Timeline of the history on the educational policy in South Africa, Sutori, 29 November. Available at https://www.sutori.com/story/ interactive-timeline-of-the-history-on-the-educational-policy-in-south-africa-xEYiK8yVhmycHJqEcLmR2X3w Accessed on 3 February 2021.

Williams, G. 2016. Higher education: Public good or private commodity? London Review of Education. 14(1):131-142.

Wolhuter, CC. 2006. Teacher training in South Africa: Past, present and future. Education Research and Perspectives. 33(2):124-139. 